\title{
Nietzsche contra Wagner: veleidade de artista, décadence e ascetismo ${ }^{1}$
}

\section{Nietzsche against Wagner: artist's levity, décadence, and asceticism}

\author{
Rodrigo Cumpre Rabelo
}

\begin{abstract}
Resumo
O artigo visa analisar a presença de Richard Wagner no contexto da crítica do velho Nietzsche ao ascetismo, nomeadamente na Terceira Dissertação de "Para a genealogia da moral" (1887). Para tanto, recorro também à idéia de gaia ciência e a elementos contidos em "O caso Wagner" (1888). O objetivo final é contribuir para um melhor entendimento não apenas da crítica ao ascetismo - que se dá desde o bojo da tarefa maior de uma revaloração de todos os valores, pautada quase sempre pela idéia de vontade de poder-, mas também, e mais especialmente, do conceito de arte e seus usos, na derradeira filosofia nietzscheana.
\end{abstract}

Palavras-chave: Arte. Ascetismo. Modernidade. Nietzsche. Wagner.

\begin{abstract}
The article aims to analyze the presence of Richard Wagner in the context of old Nietzsche's critique of asceticism, namely in the Third Inquire of "Toward the genealogy of morals" (1887). To do so, I also apply the idea of gay science and elements from "The case of Wagner" (1888). In the end I hope to contribute not only for a better understanding of that critique - which transpires from within the bigger task of a revaluation of all values based, almost always, on the idea of will to power- but also, and more especially, of the concept of art and its uses, in the last nietzschean philosophy.
\end{abstract}

Keywords: Art. Asceticism. Modernity. Nietzsche. Wagner.

\section{Introdução}

Em "Para a genealogia da moral", Nietzsche inicia o $\S 2$ da Dissertação sobre o ideal ascético, considerando o exemplo de Richard Wagner e sua tardia "homenagem" à idéia de castidade: "num certo sentido ele sempre o fez; mas apenas bem no final em um sentido ascético" (NIETZSCHE, 1998, p. 88). Considera que essa mudança de sentido (de não-ascético para ascético) não é uma mudança qualquer, trata-se de uma "radical reviravolta do senso" no caso de um artista: "O que significa um artista virar seu oposto?” (NIETZSCHE, 1998, p. 88). Aqui está embutida a afirmação que o artista é (ou deveria ser) o oposto do ideal ascético.
Nietzsche introduz assim uma pista importante sobre a posição do artista em sua análise; porém, a deixa de lado por enquanto, e volta sua atenção à análise do significado da oposição.

Essa, "oposição trágica" contraria a realidade efetiva segundo Nietzsche a vê (ou seja, sua idéia de vontade de poder). O exemplo da "castidade" é exemplo da ótica asceta: desagrega, cria oposições inconciliáveis porque lhe falta força plástica para sínteses que lhe permitiriam estabelecer relações dinâmicas, produtivas. "Pois entre castidade e sensualidade não há oposição necessária [...]. Mesmo no caso em que há realmente oposição entre castidade e sensualidade, ela felizmente não precisa

1 Contém trechos, bastante modificados, de Dissertação de Mestrado publicada na Biblioteca Virtual da UNICAMP.

2 Professor Colaborador Adjunto do Dep. de Filosofia da Universidade Estadual de Londrina (UEL). Doutor em Filosofia pela Universidade Estadual de Campinas (UNICAMP). E-mail: rrabelo@uel.br . 
ser uma oposição trágica" (NIETZSCHE, 1998, p. 88). Uma oposição trágica seria, assim, aquela em que o sujeito em questão, em face de apenas duas possibilidades opostas e irreconciliáveis, vê-se obrigado a uma escolha fatal; uma oposição nãotrágica (agonística). Esta, por sua vez, seria aquela em que, adotando a ótica da vontade de poder, o sujeito percebe como suplementares caminhos aparentemente "opostos".

Ora, a vida difere da tragédia no sentido em que não admite nem oposição nem dialética, mas apenas conflito entre forças divergentes. A vida estabelece uma relação suplementária ao invés de oposição entre sensualidade e castidade. A castidade é uma "atração suplementar" que a vida fornece à sensualidade. É um ingrediente estimulante na vida sexual, dando a esta todo o seu sal e tempero (KOFMAN, 1994, p. 199, tradução nossa).

$\mathrm{Na}$ verdade, para Nietzsche, a castidade é um exemplo de prática ascética (uma prática apropriada pelo ascetismo) que pode ser estimulante não só sexual, mas para todo tipo de fecundidade, de "maternidade" [cf. "Para a genealogia da moral", III, $\S 8]$. Uma oposição desse tipo só caberia àqueles que julgam precisar da castidade, porque, de fato, não têm controle sobre seus impulsos -algo mais parecido com um porco do que com um ser humano, no comando de suas capacidades [idem, III, § 2; cf. "Aurora”, § 332]-. O ideal ascético transforma o homem num ser que só se preocupa com suas necessidades mais básicas e limitadas e fixas, não permitindo espaço para a criatividade do "espírito livre" (KOFMAN, 1994, p. 199-200). Assim como na caso da "moral do senhor/moral dos escravos", também nesse registro encontra-se a análise a partir dos dois tipos básicos: o abundante e o débil [v. "A gaia ciência”, § 370]. Este último é fraco, o que não é (e a quem não é possível ser) "cônscio de suas energias criadoras e de uma consciência de artista” (NIETZSCHE, 1992, p. 131).
$\mathrm{Na}$ seqüência do texto de "Para a genealogia da moral", faz-se presente a ideia de gaia ciência, no campo da crítica a Wagner: fosse o último Wagner grandioso, seu Parsifal seria uma paródia, uma comédia, não seria a sério, e, assim, Wagner não se teria despedido de modo "propriamente digno de um grande trágico: o qual, como todo artista, somente então chega ao cume de sua grandeza, ao ver a si mesmo e à sua arte como abaixo de si - ao rir de si mesmo" (NIETZSCHE, 1998, p. 89). Esse trecho remete ao tema da superação de si, que Nietzsche desenvolve desde pelo menos "Humano, demasiado humano", na figura do "espírito livre". Nesse sentido, pode-se considerar: (1) a perspectiva descrita pelo desenvolvimento do "espírito livre" que "viu abaixo de si uma multiplicidade imensa" de coisas que "lhe dizem respeito" mas "que não mais o preocupam" (NIETZSCHE, 2000, p. 11); (2) a descrição do "cume da grandeza" do artista; (3) a "quase serena e curiosa frieza do psicólogo, que toma posteriormente uma multidão de coisas dolorosas, que tem abaixo de si, atrás de si, e ainda as fixa para si mesmo e como que as espeta com alguma ponta de agulha" (NIETZSCHE, 1999a, p. 104). Pode-se, então, considerar essas passagens, e outras semelhantes, sob um mesmo sentido norteador, qual seja: a "superação de si" por alguém que aprendeu a "digerir" suas vivências a partir de uma "grande saúde" (i.e., livrando-se do ressentimento). Ainda a partir desse ponto de vista Nietzsche acredita escrever, por isso prega que só se deve falar "daquilo que se superou" (NIETZSCHE, 1999a, p. 103). Esse indivíduo assim maturado, assim emancipado, ri de si mesmo, no sentido da consciência sobre a sua relativa insignificância de si mesmo e de suas obras.

Mas um Wagner "comediante" é apenas uma hipótese que Nietzsche aventaria; a realidade é que a intenção de Wagner com seu Parsifal foi séria3; e, com isso, ele incorre numa veleidade: a veleidade do artista.

Em "Para a genealogia da moral” isso é afirmado paulatinamente; em “O caso Wagner” (1888) é já um pressuposto. 


\section{A Veleidade de Artista}

Nesse momento, é oportuno analisar a relativa desconsideração de Nietzsche quanto ao papel do artista, já anunciada no aforismo inicial ${ }^{4}$ e depois repetida: "O que significam então ideais ascéticos? No caso de um artista, já o compreendemos: nada absolutamente!... ou tantas coisas, que resultam em nada!...” (NIETZSCHE, 1998, p. 91). Que significa isto agora se, como visto a pouco, Nietzsche também afirma que o artista corresponde ao oposto do ideal ascético? É um passo que exige atenção, constitui uma distinção complexa a ser feita no percurso em questão.

Nietzsche explica por que os artistas devem ser descartados, se o que se busca é apreender o significado do ideal ascético: "eles estão longe de se colocarem independentemente no mundo, e contra o mundo, para que suas avaliações, e a mudança delas, mereçam em si interesse" (NIETZSCHE, 1998, p. 92). Entenda-se: um artista não pode responder o quê significa o ideal ascético, pois ele nada tem a ver, originalmente, com esse ideal ${ }^{5}$. O artista pode apenas instrumentalizá-lo, parasitá-lo de acordo com um interesse superficial, uma espécie de "veleidade": um capricho, um desejo equivocado de ser "real", do qual só faz sentido Nietzsche falar especificamente no caso do artista stricto sensu.

Wagner é então o caso exemplar para o entendimento da lógica do ascetismo em relação aos artistas. Nietzsche o considera um "caso típico" da "típica veleidade do artista" ["Para a genealogia da moral”, III, § 4], qual seja: renunciar à sua condição de "enganador", de afirmador das aparências, e sucumbir à tentação de ser "real", de participar da autoridade da "verdade". No caso em foco: Wagner deixa de seguir o "sensualismo sadio" de Feuerbach [cf. id., III, § 3] para seguir o pessimismo asceta de Schopenhauer, mais em voga na época (década de 1870), portanto mais poderoso e interessante como anteparo [cf. III, § 5]. Nesse momento, ele está, segundo Nietzsche, reforçando a debilidade dos artistas enquanto agentes determinantes da realidade:

[os artistas] sempre foram criados de quarto de uma religião, uma filosofia, uma moral; sem contar que, infelizmente, não raro foram dóceis cortesãos de seus seguidores e patronos ${ }^{[6]}$, e sagazes bajuladores de poderes antigos, ou poderes novos e ascendentes. Ao menos necessitam sempre de uma proteção, um amparo, uma autoridade estabelecida: os artistas não se sustentam por si sós, estar só vai de encontro a seus instintos mais profundos. (NIETZSCHE, 1998, p. 92).

Está em realce aqui essa forma de agir - o parasitar algo mais fundamentado, de maior autoridade, mais poderoso -, e não o conteúdo: se para Wagner coube o ascetismo à Schopenhauer, um outro artista poderia usar, e.g., até mesmo o hedonismo para os mesmos fins (atender à "veleidade"), e assim por diante. Pensando nessa veleidade flutuante, Nietzsche anuncia que, para os artistas, os ideais ascéticos significam "nada": para eles não interessa o ideal ascético per si, mas por sua "proteção" e seu poder.

No que diz respeito ao caso específico, um artista adotar o ideal ascético não é apenas uma veleidade

\footnotetext{
4 "O que significam ideais ascéticos? Para os artistas nada, ou coisas demais" (NIETZSCHE, 1998, p. 87).

5 Dito em outras palavras: "num artista verdadeiro, o ideal ascético não possui nenhuma significação: simples empréstimo superficial, sugerido pelo caráter dominante de uma tábua de valores, ele não traduz, em profunda, um modo de interpretação exigido pelo estado dos instintos, como é o caso para o padre" (WOTLING, 1999, p. 5, tradução nossa); cf. "Para a genealogia da moral", III, § 4).

6 "Os artistas glorificam sem cessar não fazem outra coisa todos aqueles estados e coisas que têm a reputação de fazer o homem sentir-se bom ou grande, ébrio, divertido, são e sábio. Tais coisas e estados seletos, cujo valor para a felicidade humana é tido por certo e estabelecido, são os temas dos artistas: estes se acham sempre à espreita, para descobrir coisas assim e transportá-las para o domínio da arte. Quero dizer que eles não são os aferidores da felicidade e do que é feliz, mas que sempre ficam próximos desses aferidores, com enorme curiosidade e desejando utilizar imediatamente as avaliações deles. [...] E quem são estes? São os ricos e os ociosos" (NIETZSCHE, 2001, p. 114).
} 
entre outras, é a pior possível:

Um artista inteiro e consumado está sempre divorciado do "real", do efetivo; por outro lado, compreende-se que ele às vezes possa cansar-se desesperadamente dessa eterna "irrealidade" e falsidade de sua existência mais íntima - e faça então a tentativa de irromper no que lhe é mais proibido, no real, a tentativa de ser real. Com que êxito? Fácil adivinhar... Eis a típica veleidade do artista (NIETZSCHE, 1998, p. 91).

Esse é, ainda, o porquê de Nietzsche dizer que, para os artistas, o ideal ascético significa "coisas demais". Quando analisa o caso especificamente, por meio da pergunta "o que significa um artista virar seu oposto?" ["Para a genealogia da moral", III, § 2], Nietzsche desdobra várias explicações, mas não as que realmente importam: são coisas que dizem respeito à situação particular do artista, não sobre o significado do ideal ascético para o homem em geral.

Essas idéias serão ainda retomadas mais à frente, pois Nietzsche as reitera na segunda análise da arte, § 25. Por ora, já é possível explicitar por que motivo os artistas não são capazes de ser "reais" (eles "não se sustentam por si sós", sentencia o autor (NIETZSCHE, 1998, p. 92)). Por que o artista "puro" encontra-se sempre separado do que é "real"? Porque, segundo Nietzsche, ele precisa dessa distância para dar à luz suas obras. É mister manter essa distância entre artista e obra ${ }^{7}$, tanto para desfrutá-la (espectador) quanto para produzila (artista autêntico), e não cair na tentação de confundir os dois elementos,

[...] como se ele mesmo [o artista] fosse o que é capaz de representar, conceber, exprimir. $\mathrm{Na}$ verdade, se ele o fosse, não o poderia representar, conceber, exprimir; um Homero não teria criado um Aquiles, um Goethe não teria criado um Fausto, se Homero tivesse sido um Aquiles, e
Goethe um Fausto (NIETZSCHE, 1998, p. 91).

Considerando a problemática situação existencial do homem, pode-se entender porquê o artista "às vezes possa cansar-se desesperadamente dessa eterna 'irrealidade' e falsidade de sua existência mais íntima" (NIETZSCHE, 1998, P. 91), e caia na referida "veleidade", ou seja, "faça então a tentativa de irromper no que lhe é mais proibido, no real, a tentativa de ser real" (NIETZSCHE, 1998, P. 91). Isso envolve toda a fisiologia empregada por Nietzsche a serviço de sua doutrina da vontade de poder: "Certas condições determinadas -aquelas de uma decadência fisiológica- permitem-nos entender que um artista necessite aproveitar-se do ideal ascético para seu uso próprio" (KOFMAN, 1994, p. 196, tradução nossa).

Essas caracterizações podem dar a entender que Nietzsche despreza os artistas por não serem capazes de tomar o caminho filosófico da distância e da solidão para, então, poderem se colocar contra o mundo para que suas avaliações pudessem ter valor em si. Mas a análise da veleidade do artista mostra antes o contrário: Nietzsche sublinha que o artista deve se manter assim, sob o preço de, em não se contendo, assinar sua sentença de morte enquanto artista. Assim, além de apenas apontar a inépcia dos artistas enquanto constituidores da "realidade", faz-se mais relevante entender de que modo e por quais motivos Nietzsche insiste que exatamente nisso reside a função e o poder do artista, e que precisamente assim ele deve permanecer.

Para Nietzsche, a natureza é ilusão; afirmar a vida é afirmar a ilusão. Ele constrói uma perspectiva segundo a qual a realidade deve ser afirmada sem oposições e/ou parcialidades metafísicas mendaciosas: também o terrível e o árduo devem ser afirmados. A perspectiva moral não quer e não é capaz de fazê-lo, já que descende do ressentimento

\footnotetext{
7 Aliás, o ponto máximo de realização para um artista corresponde, segundo Nietzsche, ao ponto máximo de distanciamento e de não-"seriedade", onde ele menos valoriza sua própria obra: "todo artista somente então chega ao cume de sua grandeza, ao ver a si mesmo e à sua arte como abaixo de si ao rir de si mesmo" (NIETZSCHE, 1998, p. 89).
} 
o que opera a dicotomia fundamental do ascetismo, a saber, aquela entre realidade e ilusão, bem e mal. Somente a arte é capaz disso: afirmar a totalidade, e ainda embelezá-la, potencializá-la. "Através de sua vontade de ilusão, a arte 'imita' uma vida que vive na ilusão, portanto afirmando a vida e querendo-a novamente. [...] A arte é um culto de superfícies, e educa o homem a querer brincadeira e ilusão, não 'realidade' ou verdade" (KOFMAN, 1994, p. 195, tradução nossa).

Como no artista a "boa consciência" para com a aparência encontra-se em sua natureza mais íntima, querer-se como "real" constitui uma veleidade; mais: constitui, propriamente, "a típica veleidade do artista" ["Para a genealogia da moral”, III, § 4] e "infelizmente das mais corriqueiras: pois nada é mais corruptível do que um artista" (NIETZSCHE, 1998, p. 141).

\section{Função Descritiva da Obra de Arte}

Pois bem: se os artistas não criam propriamente a realidade, o que fazem eles? O que um artista pode (ou deve, para não cair na veleidade) fazer em relação a ela? Numa palavra: ele a descreve ${ }^{8}$. Para Nietzsche, dizer que o artista apenas "descreve" não é pouco, pois significa que ele "louva", "glorifica", "elege", "prefere" e, em o fazendo, "fortalece ou enfraquece certas estimativas de valor" (NIETZSCHE, 1999a, p. 382). Se o artista "fortalece ou enfraquece certas estimativas de valor", quer dizer que ele (qua artista, ou seja, como produtor-de-obras-de-arte) não cria, propriamente, essas estimativas; elas advêm, portanto, de outrem. O criador de valores -nesse sentido (especificamente nietzscheano), o criador da realidade é (preferencialmente) o filósofo:

[...] o artista puro, diferente do filósofo, não pode e não deve criar valores ou dedicar-se a procurar verdades proposicionais. Ele não pode fazê-lo porque ele é incapaz, qua artista, de tomar as posições independentes necessárias para criar valores ou procurar verdades proposicionais (MAY, 1999, p. 31, tradução nossa).

Quem quer que crie avaliações ou interpretações próprias está sendo "artista" de acordo com o sentido lato nietzscheano. Preferencialmente Nietzsche atribui essa criação ao filósofo ("do futuro" ${ }^{10}$ ), ma acrescenta que também o sacerdote, o "senhor", o "nobre", ou até mesmo a "besta loira", exerceram tal poder de plasmação, de "legislação". Mas o filósofo, espírito verdadeiramente lúcido, liberto e potente, deverá ser o legislador e líder do futuro da Humanidade, através da instituição de valores:

para onde apontaremos nós as nossas esperanças? -Para novos filósofos, não há escolha; para espíritos fortes e originais o bastante para estimular valorizações opostas e revalorar e transtornar "valores eternos", para precursores e arautos, para homens do futuro que atem no presente o nó, a coação que impõe caminhos novos à vontade de milênios. [...] [P] ara isto será necessária, algum dia, uma nova espécie de filósofos e comandantes, em vista dos quais tudo o que já houve de espíritos ocultos, terríveis, benévolos, parecerá pálido e mirrado. É a imagem de tais líderes que paira ante os nossos olhos (NIETZSCHE, 1992, p. 103) ${ }^{11}$.

É dito que "um artista inteiro e consumado está sempre divorciado do "real", do efetivo" (NIETZSCHE, 1998, p. 91): essa é a descrição de nada além que sua atividade própria, quando

\footnotetext{
8 O descrever do artista, está claro, não é o mesmo que aparece criticado em outro contexto, com relação à suposta "isenção" do historiógrafo que se recusa a interpretar, e que quer apenas "descrever" [cf. "Para a genealogia da moral", III, § 26].

9 "Louvor na escolha. O artista escolhe sua matéria: é sua forma de louvar" (NIETZSCHE, 2001, p. 181).

10 "a tarefa futura do filósofo, sendo esta tarefa assim compreendida: o filósofo deve resolver o problema do valor, deve determinar a hierarquia dos valores" (NIETZSCHE, 1998, p. 46).

${ }^{11}$ E ainda: "os autênticos filósofos são comandantes e legisladores: eles dizem 'assim deve ser!', eles determinam o para onde? e para quê? do ser humano [...] estendem a mão criadora para o futuro, e tudo que é e foi torna-se para eles um meio, um instrumento, um martelo. Seu 'conhecer' é criar, seu criar é legislar, sua vontade de verdade é vontade de poder. Existem hoje tais filósofos? Já existiram tais filósofos? Não têm que existir tais filósofos?...” (NIETZSCHE, 1992, p. 118).
} 
exercida de modo autêntico. Ele deve manterse distanciado do real (criação de valores) para poder "representar", “conceber", "exprimir" [id.] esse mesmo real. Num sentido mais prosaico, isso quer dize, simplesmente, que se Homero fosse um homem de ação, não teria as condições para (e/ou a necessidade de) conceber um Aquiles; sendo artista, ele é um homem talhado mais para a contemplação, que pode-quer representar, exprimir, descrever. Num sentido mais profundo, porém, essa distância significa que o artista só pode representar, exprimir, descrever, a partir de ou a respeito desse real, uma vez que não o cria-. Ao mesmo tempo, só ao restringir com boa consciência (Gewissen) à função descritiva de suas obras, ele estará sendo propriamente artista, e "idealizar" (no sentido nietzscheano [v. "Para a genealogia da moral", III, $\S 26]$ ) a realidade, ou seleções de realidades, sem a pretensão (veleidade) de falar a "Verdade", de ser "uma espécie de porta-voz do 'em si' das coisas, um telefone do além” (NIETZSCHE, 1998, p. 93).

A função do artista, no sentido estrito é, assim, relativa à relação entre verdade e mentira, realidade e ficção. Isso indica o teor das próximas considerações.

\section{Arte e Verdade}

A função do artista na primeira análise ${ }^{12}$ da arte na Terceira Dissertação está relacionada com a questão maior da "verdade" em Nietzsche, da qual não é possível tratar, aqui, com o vagar e a extensão por ela demandados. Minimamente, no entanto, deve-se considerar que, em sua obra, ele opera uma inversão nessa questão. A "Verdade" tradicionalmente concebida universal, eterna, imutável é para ele propriamente uma ficção, um necessário auto-engano experimentado ${ }^{13}$ pelo homem desde os graus mais recuados de sua constituição cognitiva (como descrito especialmente no texto não publicado "Sobre verdade e mentira no sentido extramoral"), e sedimentado, ao longo de eras, também por outros motivos (de ordem moral, cf. "Para a genealogia da moral"). Essa "verdade" é o nada, é a negação do mundo, se se entender, como Nietzsche entende, que o mundo é constante devir, e que a verdade é um construto da particular perspectiva humana. Isso não quer dizer que ele abandone toda ambição a obter e sustentar juízos que considere como verdadeiros ${ }^{14}$. Sob a égide da doutrina da vontade de poder, "Nietzsche substitui o ideal do conhecimento, a descoberta do verdadeiro, pela interpretação e avaliação" 15 (DELEUZE, 1965, p. 17, tradução nossa).

No mesmo sentido, percebe-se que Nietzsche distingue diferentes valores referentes a diferentes tipos de "mentira"; e.g., cristianismo versus sonhos: "Esse mundo de pura ficção [do cristianismo] diferencia-se do mundo sonhado, com enorme desvantagem sua, pelo fato de este último refletir a realidade, enquanto ele falseia, desvaloriza e nega a realidade" (NIETZSCHE, 2007, p. 20-21). O

${ }^{12}$ A outra análise direta da arte encontra-se no parágrafo 25, no qual Nietzsche opõe Homero a Platão.

${ }^{13}$ Concomitantemente nos dois sentidos do termo, quais sejam, de sofrer algo e de testar algo.

${ }^{14}$ Sobre esse particular, a posição sustentada (exemplarmente) por Richard Schacht parece ser das mais razoáveis e proveitosas para uma leitura coerente e construtiva do pensamento nietzscheano. V.: SCHACHT, 1983, Cap. II, e SCHACHT, 2000.

15 Essa "substituição" a que Deleuze se refere é vista por Günter Abel mais como complementação:

O grau de verdade de uma interpretação depende: (i) da relevância da interpretação para o indivíduo; (ii) do enraizamento e da firmeza da interpretação dentro do corpus de interpretações; (iii) da capacidade de coalizão com outras interpretações; (iv) da aptidão para poder ser adotada pela malha das interpretações já existentes; (v) da capacidade de organizar nossa experiência de forma mais abrangente e simples do que até hoje; (vi) da força de poder contribuir para a intensificação de experiência; (vii) da liberação de perspectivas diferentes e também convergentes e (viii) do transcender horizontes estreitos e da capacidade de abrir novos horizontes da interpretação. Os primeiros cinco aspectos podem servir, ao mesmo tempo, para reformular a concepção de verdade de acordo com o esquema antigo (isto é, a verdade no sentido do fixar, do "prender"). Mas os três últimos aspectos citados dizem respeito mais ao novo sentido do discurso da "verdade da interpretação". Esse novo sentido é referente ao não fixável fluxo das interpretações, ao constante fluir das coisas do mundo e da vida (ABEL, 2002, p. 50-51). 
critério decisivo é saber qual a posição fundamental que se perceba ter sido a adotada pela "estimativa de valor", por trás da "mentira", em relação ao caráter mais íntimo da existência tal como entendido por Nietzsche: se se afirma o devir (vontade de poder), tem-se a ficção de "boa consciência", a arte autêntica; se se o nega (niilismo metafísico), tem-se a falsificação, o ideal ascético.

A tarefa distintiva do artista é o melhor exemplo de "mentira", ao mesmo tempo necessária, desejável e estimulante, A "aparência" que o artista estima significa "novamente a realidade, mas numa seleção, correção, reforço"; ele não a nega como o pessimistaromântico-asceta, "ele diz justamente Sim a tudo questionável e mesmo terrível, ele é dionisíaco..." (NIETZSCHE, 2006, p. 29). Por isso, esse tipo de artista se diferencia irredutivelmente de outros que também interpretam a realidade, falsificando-a negativamente através de seus valores. O termo a que Nietzsche recorre para designar, neste sentido, tanto Schopenhauer quanto Wagner, é "moedeiro falso" ("Falschmünzer") (NIETZSCHE, 1999b, p. 30-35).

Essas considerações remetem, por fim, ao "realismo do símbolo" que Erich Heller apreende no quadro do último período do pensamento nietzscheano, com relação à função-produção dos artistas (qua artistas no sentido estrito):

[...] o problema que é [para Goethe] "mais fundamental que a questão sobre a certeza do conhecimento": o problema dos valores. A resposta jaz no realismo de Goethe tal como entendido por Nietzsche. É o realismo do símbolo; não do obscuro símbolo atirado pelo coletivo inconsciente dos simbolistas, invadindo as cascas de memórias mortas com significações sonhadas e não-sonhadas; nem do símbolo que se refere a abstrações, na maneira de uma alegoria [...]. Esse realismo do símbolo é a propriedade comum a toda grande arte. Esta não esmera-se em comparação a uma esfera ideal que possa redimir a prosaica indignidade desse mundo (como faz a arte de Schiller), nem procura libertação do terror da verdade na curativa irrealidade da "schöner Schein" (como cria o jovem Nietzsche), nem usa autoconscientemente sonhos e pesadelos, agradável ou desagradavelmente, para franzir a entediante lisura da superfície da vida. Ela descreve e, em descrevendo, abre nossos olhos para aquilo que realmente é. E o que realmente é não é um sonho ou sombra, nem a agonia sem significado da Vontade, nem as abstrações da Razão, mas a vivente revelação do insondável (HELLER, 1988, p. 29-30, tradução nossa).

Essa "vivente revelação" do "insondável" que funda e permeia a (verdadeira) realidade é tomada por Nietzsche como vontade de poder. Ora, se a vida é entendida como vontade de poder, qual o significado da afirmação de que "a arte é o grande estimulante para a vida" (NIETZSCHE, 2006, p. 77). Um estimulante (Stimulans) é algo que desperta, excita; algo que desperta e excita "para a vida" significa, em Nietzsche, "tudo o que eleva o sentimento de poder, a vontade de poder, o próprio poder no homem", em oposição a "tudo o que vem da fraqueza” (NIETZSCHE, 2003, p. 11). Reconhece-se que um artista e sua obra não advêm da fraqueza quando ele afirma o mundo, quando "ele diz justamente Sim a tudo questionável e mesmo terrível" (NIETZSCHE, 2006, p. 29). Assim, a arte bem lograda é benfazeja: representa e estimula os instintos criadores, tão massacrados pelos ideais de cunho ascético (SCHACHT, 1983, p. 523-s).

\section{Wagner}

O que significa, então, a posição ímpar de Wagner no contexto dos primeiros movimentos da Terceira Dissertação? Por que constitui ele "talvez o maior exemplo de autoviolentação na história das artes" (NIETZSCHE, 1999b, p. 33).

Nietzsche julga poder ler Wagner melhor que este a si próprio: "não devemos nos deixar enganar por seus próprios malentendidos a seu respeito -é raro que um gênio da sua espécie tenha a prerrogativa de se compreender" (NIETZSCHE, 1992, p. 166). Essa prerrogativa Nietzsche julga 
possuir, de maneira inconteste ${ }^{16}$, especialmente a partir de sua análise da décadence ${ }^{17}$. Da maneira mais geral, Nietzsche entende a "decadência" como desagregação da vontade: “o todo já não é um todo” (NIETZSCHE, 1999b, p. 23); desagregação é sintoma de uma vontade doente. Considerar o conceito de decadência significa ter que considerar a idéia de fisiologia de Nietzsche, uma vez que ele afirma que suas “objeções à música de Wagner são fisiológicas" (NIETZSCHE, 2001, p. 270). O que significam, portanto, fisiologia e decadência para Nietzsche, e como ele as relaciona?

\section{Fisiologia e Décadence}

Que significa, comumente, "fisiologia”, estudo sobre a natureza (physis)? Há para esse vocábulo dois usos principais registrados: 1) na História Natural: "ciência dos fenômenos da vida e das funções dos órgãos, tanto dos animais como dos vegetais: fisiologia animal; fisiologia vegetal; fisiologia comparada"; 2) na Literatura: "Estudo de um caráter considerado como tipo ou de um estado especial e característico (AULETE, 1974, p. 1608). A fisiologia do comediante; a fisiologia do casamento." Há momentos em que a fisiologia de Nietzsche pende mais para o primeiro uso, outros, para o segundo; e há momentos em que parece ser uma sobreposição ou entrecruzamento das duas, quando define sua psicologia como "fisio-psicologia", "o caminho para os problemas fundamentais", "para cujo serviço e preparação existem as demais ciências" (NIETZSCHE, 1992, p. 30). Nesse mesmo sentido de "rainha das ciências", a fisiologia aparece na Nota que encerra a Primeira Dissertação [v. "Para a genealogia da moral", I, Nota do autor].

Wolfgang Müller-Lauter percebe, no uso nietzscheano de "fisiologia", três determinações gerais, que "se sobrepõem com freqüência": 1) "o uso da palavra 'fisiologia' feito pelas ciências de sua época"; 2) a determinação somática "(e por isso fundamental)" dos homens somático refere-se, aí, tanto às funções orgânicas quanto "ao efetivo no sentido do imediato corpóreo"; 3) a interpretação dos processos fisiológicos "como a luta de quanta de poder que ‘interpretam' sejam esses quanta um povo, um homem, uma célula (MÜLLER-LAUTER, 1999, p. 21-22). A esta última determinação subsume-se o "corpo", entendido como um rótulo que apenas denomina a pluralidade continuamente mutante de vontades de poder que constitui cada homem (MÜLLER-LAUTER, 1999, p. 22-23). Com as três determinações, o comentador julga que "podese descrever décadence como perda da capacidade de organização. Segue-se daí desorganização ou desagregação de uma pluralidade reunida num todo: desintegração de uma estrutura disposta em ordem.” (MÜLLER-LAUTER, 1999, p. 24-25). A partir desse conceito, "Nietzsche contrapõe sua resistência fisiológica à refutação fisiológica de Wagner (15 [111] da primavera de 1888; 16 [75] e 16 [80] da primavera/verão de 1888. Cf. "O caso Wagner”, Posfácio e Epílogo). O doente torna doente ("O caso Wagner", $\S 5 ; 16$ [75] da primavera/ verão de 1888); então, ele tem de ser combatido" (MÜLLER-LAUTER, 1999, p. 17).

Esse combate se desenrola em duas frentes: a crítica à música de Wagner (decadência artística) como sintoma e agravante da doença moderna (decadência fisiológica), doença da qual Wagner constitui o exemplo mais acabado. Mas, considera Müller-Lauter, a relação direta entre esses dois aspectos não chega a ser determinada de modo definitivo.

Se se procurar extrair de tudo isso um resultado,

16 “'Sou, em questões de décadence, a mais alta instância que agora existe sobre a Terra' (carta 1131), escreve Nietzsche de Turim, em 18 de outubro de 1888, a Malwida von Meysenbug, com cuja resposta ao envio do Caso Wagner se sentira ofendido" (MÜLLER-LAUTER, 1999, p. 11; cf. “Ecce homo”, Por que sou tão sábio, § 1).

${ }^{17}$ Nietzsche mormente escreve o termo em francês, seguindo sua fonte principal no assunto, o psiquiatra francês Paul Bourget (MÜLLER-LAUTER, 1999). 
pode-se dizer tão-só que Nietzsche vê o que chama de décadence artística numa relação de dependência -e, ocasionalmente, também apenas numa relação de correspondência- com o que descreve como décadence fisiológica. A espécie de dependência ou a particularidade de correspondência nele não encontram uma explicação unânime (MÜLLER-LAUTER, 1999, p. 24).

Isso porque a postura do próprio Nietzsche em relação ao status da sua fisiologia varia, principalmente de $1888^{18}$ para os anos anteriores. Até 1887, a postura é mais cautelosa, tem caráter hipotético: "objeções" (como as que constam no $\S 368$ de "A gaia ciência") não são explicações. Nesse período, o corpo é um fio condutor para as investigações; mas a fisiologia não chega a constituir explicação última: ela é uma porta de entrada melhor que as explicações metafísicas ${ }^{19}$, porém, ainda se trata de "fatos que até agora não puderam ser formulados com exatidão" (NIETZSCHE, 1998, p. 118) ${ }^{20}$. Já em 1888, especialmente em "O caso Wagner", Nietzsche parece incorrer temporariamente, conforme observa Müller-Lauter, num reducionismo ao fisiológico, o que inclusive constitui contradição com pontos de seu pensamento anterior.

Considerados os dois períodos, a conclusão mais acertada seria a de que

Se examinar a fundo a fala de Nietzsche sobre o fisiológico, percebe-se (por certo, contra a sua auto-compreensão temporária) que, por fim, a estrutura da organização hierarquicamente sintonizada é determinante e não uma interpretação fisiológica da efetividade, num sentido estreito, que estaria ela própria subordinada a uma interpretação distinta
(MÜLLER-LAUTER, 1999, p. 23).

Isso implica que essa estrutura deve ser considerada a chave de leitura para a análise das críticas de Nietzsche a Wagner.

\section{O "Artista da Décadence"}

Wagner usa sua música como um canto de sereia para "algo além"; sua arte engana, simula o grande estilo. Nietzsche confessa ter sido seduzido e enganado: "Eu fui capaz de levar Wagner a sério" (NIETZSCHE, 1999b, p. 14). Com sua "mentira do grande estilo" Wagner promove inclusive a si mesmo: "A primeira coisa que a sua arte nos oferece é uma lente de aumento: olhando por ela, não se acredita nos próprios olhos tudo fica grande, até Wagner fica grande [...]" (NIETZSCHE, 1999b, p. 12).

O que significa, para Nietzsche, o "grande estilo"? Em “Crepúsculo dos ídolos”, ele apresenta uma caracterização que evidencia a relação dessa idéia com a de nobreza baseada na doutrina da vontade de poder:

O mais alto sentimento de poder e segurança adquire expressão naquilo que tem grande estilo. $\mathrm{O}$ poder que já não tem necessidade de demonstração; que desdenha agradar; que dificilmente responde; que não sente testemunha ao seu redor; que vive sem consciência de que há oposição a ele; que repousa em si mesmo, fatalista, como uma lei entre as leis: isso fala de si na forma do grande estilo (NIETZSCHE, 2006, p. 70).

Já Wagner abandonou "todo" estilo da música [cf. "O caso Wagner", § 8]. E qual o tipo daquele que

\footnotetext{
${ }^{18}$ Ano em que "a palavra [décadence] converteu-se num dos conceitos centrais do seu filosofar. Para tanto, concorreu a leitura que fez do primeiro volume dos Essais de psychologie contemporaine (1883) de Paul Bourget, onde encontrou o conceito empregado de maneira específica" (MÜLLER-LAUTER, 1999, p. 12).

${ }^{19}$ Inclusive melhor que os "preconceitos" metafísicos que sustentavam e tolhiam a psicologia até ele, o "primeiro psicólogo da Europa". A esse respeito, cf. (GIACOIA JUNIOR, 2001, p. 15-46).

${ }^{20}$ Isso vale (ao menos até 1887) tanto para a arte quanto para a moral. A certa altura da descrição da inversão da direção do ressentimento, operada pelo sacerdote ascético, lê-se: "Sofrendo de si mesmo de algum modo [qual? não se sabe, não há explicação ainda], em todo caso fisiologicamente [i.e., o que podemos perceber]" (NIETZSCHE, 1998, p. 129).
} 
não se submete a um estilo, nem mesmo em sua arte? "[S]ão os caracteres fracos, nada senhores de si, que odeiam o constrangimento do estilo: eles sentem que, se lhes fosse imposta essa maldita coerção, debaixo dela viriam a ser vulgares: -eles se tornam escravos quando servem, eles odeiam servir." (NIETZSCHE, 2001, p. 196); um ódio como esse nada mais é que sintoma de decadência:

[...] a reivindicação de independência, de livre desenvolvimento, de laisser aller, é feita com maior fervor por aqueles para os quais nenhuma rédea seria curta demais isso vale in politicis, isso vale na arte. Mas isto é um sintoma de décadence: nosso moderno conceito de "liberdade" é mais uma prova de degeneração do instinto (NIETZSCHE, 2006, p. 93).

"Eis o ponto de vista que coloco em relevo: a arte de Wagner é doente" (NIETZSCHE, 1999b, p. 19). Por que a arte de Wagner é décadent e corrompe? Principalmente porque faz com que a música seja funcionária do ascetismo: música como placebo, como hipnose, como meio de super-excitação nervosa; efeitos nefastos, que correspondem ao procedimento do sacerdote ascético para com seu "rebanho" [v. "Para a genealogia da moral", III, $\S \S 11-s]$, efeitos os quais conseguiria por meio de expedientes característicos de sua obra. Nietzsche aponta, através de minuciosa análise das categorias musicais (ritmo, harmonia, dinâmica) em Wagner, como sua arte é uma forma de hipnose ascética. "Wagner é uma grande corrupção para a música. Ele percebeu nela um meio para excitar nervos cansadose, com isso tornou a música doente" (NIETZSCHE, 1999b, p. 19). O mecanismo de como isso se dá pode ser cotejado àquele do sacerdote ascético, tal como se encontra descrito na Terceira Dissertação, $\S \S 15-21$; por ora, será abordado junto à definição de Wagner como "ator".

\section{Wagner "Ator"}

Nietzsche não se cansa de repetir que Wagner, como artista, está entre os atores [cf. "Para além de bem e mal", § 256]; em "O caso Wagner" essa analogia se apresenta ao longo dos $\S \S 7$ a 12 e das conclusões do livro (Pós-Escritos e Epílogo). Que quer dizer essa analogia?

O que faz um ator? Essencialmente, ele finge ser outra pessoa. $\mathrm{O}$ ator não pode estar ligado à realidade; ele é aquele que transporta através da representação, da simulação, a uma "realidade" sempre fictícia. O ator mais bem sucedido em sua arte será o que obtém o maior efeito de seu fingimento, de seu ser-outro; aí ele é, paradoxalmente, tanto o mais verossímil (o que engana melhor, melhor emula uma realidade não efetiva) quanto o mais falso, porque o tempo todo ele se baseia na ficção.

Alguém é ator pelo fato de ter um juízo [Einsicht $\left.{ }^{21}\right]$ à frente dos outros homens: o que deve ter efeito de verdade não pode ser verdadeiro. Esta frase [...] contém toda a psicologia do ator, ela contém não duvidemos também a sua moral. A música de Wagner nunca é verdadeira. Mas é tida como verdadeira: e assim tudo está em ordem (NIETZSCHE, 1999b, p. 26).

A referência a "sua moral" remete à doutrina da vontade de poder tal como está presente também em "Para a genealogia da moral": a moral entendida como condição de sobrevivência de um determinado tipo, como uma "espiritualização" da vontade de poder. Esse tipo, representado por Wagner, significa para Nietzsche o declínio do artista: “o músico agora se faz ator, sua arte se transforma cada vez mais num talento para mentir" (NIETZSCHE, 1999b, p. 22). O ator é aquele que mente (finge) para os outros, mas que para isso tem que, também ele mesmo, acreditar na própria mentira que constitui sua performance $\neg$ Nietzsche não considera Brahms, por exemplo, como um "ator" da música: ele é "falso para conosco"; Wagner, ao contrário, "mente para si mesmo" [cf. "O caso Wagner", Segundo Pós-Escrito]. Exatamente esse auto-engano, a cegueira com relação ao próprio tipo, à própria constituição (não se ver como decadente), é o traço distintivo de Wagner em relação aos demais, pois permite ser decadente integralmente e até o limite,

\footnotetext{
${ }^{21} \mathrm{Na}$ tradução brasileira encontra-se Einsicht vertido para "percepção", o que não parece ser a melhor opção nesse caso.
} 
inclusive em sua arte: "Ele tinha a ingenuidade da décadence: esta era a sua superioridade. Ele cria nela, não se deteve ante nenhuma lógica da décadence" (NIETZSCHE, 1999b, p. 39). Isso se potencializa ao máximo com sua "conversão" ao pessimismo ascético de Schopenhauer: "O benefício que Wagner deve a Schopenhauer é imensurável. Somente o filósofo da décadence revelou o artista da décadence a si mesmo..." (NIETZSCHE, 1999b, p. 18; cf. "Para a genealogia da moral", III, $\S \S 5$-6). Ao conhecer o pensamento de Schopenhauer, Wagner interpreta o pessimismo ascético como o projeto para qual sua obra deveria se dirigir ${ }^{22}$. Mesmo nesse ponto Wagner não deixa de ser "ator", i.e., de enganar a si mesmo ele jamais se vê, ou a Schopenhauer, como décadent; esse julgamento é feito por Nietzsche. Dessa ingenuidade advém a segurança de Wagner e sua superioridade em contraste a outros décadents, aquilo que o torna o decadente "perfeito" [cf. "O caso Wagner", § 7].

Nietzsche considera que o pior efeito de Wagner sobre a cultura é a "teatrocracia" [cf. "O caso Wagner”, Pós-Escritos e Epílogo]. Teatrocracia é o nfato de que “os 'atores', toda espécie de atores, são os verdadeiros senhores" (NIETZSCHE, 2001, p. 253). Uma explicação de porquê tal poder é tão aversivo a Nietzsche tem a ver com sua visão do projeto de futuro ao qual a Humanidade deveria aderir: pois quando "atores" são os "senhores",

Justamente por isso, uma outra espécie de homens é sempre mais prejudicada e enfim tornada impossível, acima de tudo os grandes "construtores"; a energia de construir é paralisada; a coragem de fazer planos para o futuro distante é desestimulada; começam a faltar os gênios organizadores (NIETZSCHE, 2001, p. 253).

Estes "gênios" são facilmente identificáveis com os filósofos do futuro e a tarefa destes com a referida "construção" e "planejamento", ambos com vistas a contrapor e evitar a "degeneração global do homem" [cf. "Para além de bem e mal", § 203]. Mas, pode-se perguntar por que a teatrocracia prejudica o surgimento dessa espécie de homem? Porque o ator não se ocupa da realidade; ele é um farsante: apenas representa algo, não tem consistência nem fundamento verdadeiros.

Isso é exemplificado pela crítica de Nietzsche à figura do ator como "literato", isto é, como representação do erudito: Nietzsche despreza os "literatos" por não se apresentarem "com absoluta probidade de disciplina e aprendizado" (NIETZSCHE, 2001, p. 269). Essa crítica vale também para os compositores modernos, "que, quase sem exceção, com astuciosa engenhosidade de maneiras, de expedientes, mesmo de princípios, sabem adquirir depois, artificialmente, a aparência dessa probidade, desta solidez de educação e cultura" [ib.; v. "O caso Wagner", Pós-Escrito ${ }^{23}$ ]. Nesse sentido, pode-se explicar, ainda, porque Nietzsche afirma que "o ator não tem orgulho" (NIETZSCHE, 1999b, p. 35): este renuncia à sua individualidade ${ }^{24}$ para poder "ser" qualquer coisa -e

\footnotetext{
22 "Que aconteceu então? Um acidente. A nave foi de encontro a um recife; Wagner encalhou. O recife era a filosofia schopenhaueriana; Wagner estava encalhado numa visão de mundo contrária. O que havia ele posto em música? O otimismo. Wagner se envergonhou. Além disso, um otimismo para o qual Schopenhauer havia criado um adjetivo mau o otimismo infame. Ele envergonhouse novamente. Meditou por longo tempo, sua situação parecia desesperada... Enfim vislumbrou uma saída: o recife no qual naufragara, e se ele o interpretasse como objetivo, como intenção oculta, como verdadeiro sentido de sua viagem? Naufragar ali isso era também uma meta. Bene navigavi, cum naufragium feci...” (NIETZSCHE, 1999b, p. 17). Quando Nietzsche diz que Schopenhauer "revelou Wagner a si mesmo", é neste sentido. Wagner sempre fora (na visão do Nietzsche maduro) pessimista, cristão, decadente, mesmo suas obras anteriores que no fundo sempre trataram da "redenção" (NIETZSCHE, 1999b, p. 14-16); mas só com Schopenhauer identifica tais metas como sendo as suas.

23 “A adesão a Wagner custa caro. Vamos avaliá-lo por seu efeito na cultura. A quem o seu movimento pôs em primeiro lugar? O que cultivou e multiplicou sempre? Antes de tudo a presunção do leigo, do imbecil em arte. Esse organiza agora associações, esse quer impor seu 'gosto', esse gostaria mesmo de fazer-se juiz in rebus musicis et musicantibus [em matéria de música e músicos]. Em segundo lugar: uma indiferença cada vez maior face a todo treinamento severo, nobre e consciencioso a serviço da arte; em vez disso, a crença no gênio ou, em bom alemão: o diletantismo insolente (a fórmula se acha nos Mestres cantores)" (NIETZSCHE, 1999b, p. 35-36).
} 
justamente por isso, ele não é, de fato, coisa alguma-. Esta crítica à suposta mutifuncionalidade do homem moderno parece ter relação, para Nietzsche, com a idéia, desenvolvida principalmente em "Ecce homo" (1888/1908), do "tornar-se o que se é": com a idéia de que cada indivíduo tem uma tarefa própria a desempenhar" 25 ; e, lá também se lê que "Se uma espécie-décadence de homem ascendeu à posição de espécie suprema, isso pode acontecer somente à custa da espécie contrária, a espécie forte e segura da vida" (NIETZSCHE, 1995, p. 113). Esse tipo de homem não pode servir de base para uma sociedade do tipo ascendente ${ }^{26}$. O sucesso do tipo "ator" significa que "em culturas em declínio, onde quer que as massas tenham a decisão, a autenticidade se torna supérflua, desvantajosa, inconveniente. Apenas o ator ainda desperta o grande entusiasmo“ (NIETZSCHE, 1999b, p. 31).

$\mathrm{Na}$ arte, a teatrocracia é "o desvario de uma fé na preeminência do teatro, num direito à supremacia do teatro sobre as artes, sobre a arte..." (NIETZSCHE, 1999b, p. 36). Para Nietzsche, o teatro se tornar paradigmático é o pior desastre para as artes: pois para ele o teatro, em si, já é "sempre algo abaixo da arte, sempre algo secundário, tornado grosseiro, algo torcido, ajeitado, mentido para as massas! [...] O teatro é uma forma de demolatria em matéria de gosto, o teatro é uma rebelião das massas, um plebiscito contra o bom gosto..." (NIETZSCHE, 1999b, p. 36 ). Sendo verdade que tanto na criação da música quanto na do enredo, Wagner é sobretudo ator e não músico, então "[é] precisamente isto o que demonstra o caso Wagner: ele ganhou a multidão ele estragou o gosto, ele estragou até para a ópera o nosso gosto!'( NIETZSCHE, 1999b, p. 36). Mais que isso: essa premência do teatro sobre a música significa para Nietzsche um auto-rebaixamento da música, um decaimento da qualidade da vontade de poder que se apodera da música, representa "o fato de que a música foi despojada de seu caráter afirmativo, transfigurador do mundo, de que é música de décadence e não mais a flauta de Dioniso..." (NIETZSCHE, 1995, p. 102 - tradução alterada).

Da música, Nietzsche exige sobretudo "substância"; a de Wagner só lhe oferece "representações" [cf. "O caso Wagner", § 8]. Wagner é um artista da "exposição", da "representação", do "virtuosismo" [§ 11], seu instinto dominante era de ator [cf. § 8]. Wagner não é músico ${ }^{27}$ porque para ele a música é apenas um meio, não é "apenas" música: ora, "músico algum fala assim" (NIETZSCHE, 1999b, p. 30). Para um tal "histriômano", "a atitude é a finalidade, o drama, e também a música, são apenas seus meios" (NIETZSCHE, 2001, p. 270), porém meios para quê? No limite, para a "intoxicação" dos sentimentos ${ }^{28}$ perpetrada pelo "sacerdote" Wagner. Caracterização de Wagner como ressentido: ele

${ }^{24}$ Assim como ocorre com qualquer indivíduo na posição de espectador da arte do teatro e com aquele que nela trabalha: "No teatro se é honesto apenas enquanto massa; enquanto indivíduo se mente, mente-se para si mesmo. O indivíduo deixa a si mesmo em casa quando vai ao teatro, renuncia ao direito de ter a própria escolha, a própria língua, ao direito a seu gosto, mesmo a sua coragem, como a temos e exercitamos entre as nossas quatro paredes, em oposição a Deus e o mundo. Ninguém leva consigo ao teatro os mais finos sentidos da sua arte, nem o artista que trabalha para o teatro" (NIETZSCHE, 2001, p. 270-271).

25 “'A] 'idéia' organizadora, a destinada a dominar ela começa a dar ordens, lentamente conduz de volta dos desvios e vias secundárias, prepara qualidades e capacidades isoladas que um dia se mostrarão indispensáveis ao todo. Constrói uma após outra as faculdades auxiliares, antes de revelar algo sobre a tarefa dominante, sobre 'fim', 'meta', 'sentido"' (NIETZSCHE, 1995, p. 48-49).

26 “o homem só tem valor e sentido enquanto é uma pedra num grande edifício: para isso ele tem, antes de tudo, que ser firme, ser 'pedra'... E, sobretudo, não ser ator! Em poucas palavras ah, sobre isto haverá silêncio por muito tempo!, o que doravante não mais será construído, não mais pode [kann] ser construído, é uma sociedade no velho sentido da palavra; para construir tal edifício falta tudo, a começar pelo material. Nós todos já não somos material para uma sociedade: eis uma verdade cuja hora chegou!" (NIETZSCHE, 2001, p. 253). Com esse trecho exemplifica-se a aplicação e a importância, referente ao âmbito coletivo, daquele parâmetro que Müller-Lauter sintetiza como "a estrutura da organização hierarquicamente sintonizada".

${ }^{27}$ Tampouco seria Wagner uma dramaturgo [cf. "O caso Wagner”, § 9]; “Carmen”, de Bizet, é o exemplo máximo do que Nietzsche considera um verdadeiro drama. 
"se vinga de todas as coisas" com sua "vontade de eternizar" a sua imagem de "grande sofredor", "a imagem de sua tortura" (NIETZSCHE, 2001, p. 274). Portanto, para Nietzsche, não só Wagner é ator no sentido artístico, pelo modo em que se expressa e obtém seus efeitos, como também no sentido geral, como falseador da grandiosidade, como alguém que apenas "macaqueia" a "alma em maré alta" [“A gaia ciência”, § 86]. Wagner é um impostor, um "ator", porque afeta grandeza, sem dela ser verdadeiramente capaz, nem de real pensamento ou de real paixão [cf. id.], ele emite apenas um "grito teatral [destaque acrescentado] da paixão” (NIETZSCHE, 2001, p. 14).

Qual é o espírito da música autêntica? O que Nietzsche quer, afinal, da música, sob a óptica "fisiológica"? Não, certamente, o entorpecimento da consciência pelo desenfreio dos sentimentos; mas o alívio do próprio corpo [cf. "A gaia ciência”, § 368]. O que significa, no caso, um tal "alívio"? Seria de se esperar, de acordo com a vigente perspectiva ressentido-decadente, algo que apazigue, acalme, amorteça; ora, verifica-se uma feliz coerência quando se vê Nietzsche esclarecer que se trata exatamente do contrário: alívio para ele é "como se todas as funções animais fossem aceleradas [destaque acrescentado] por ritmos leves, ousados, exuberantes, seguros de si; como se a brônzea, plúmbea vida fosse dourada por boas, ternas, áureas harmonias." (NIETZSCHE, 2001, p. 270) (cf. "Ecce homo", Por que sou tão inteligente, $\S 7^{29}$ ). Essa descrição relaciona-se, por extensão, à concepção mesma de "espiritualidade" nietzscheana: a do homem finalmente naturalizado. Nietzsche clama, portanto, por uma música "espiritual", como descreve que a de Bizet é para ele: “ '[o] que é bom é leve, tudo divino se move com pés delicados': primeira sentença da minha estética" (NIETZSCHE, 1999b, p. 11); pois, pergunta logo à frente, "Já se percebeu que a música faz livre o espírito? que dá asas ao pensamento? que alguém se torna mais filósofo, quanto mais se torna músico?" (NIETZSCHE, 1999b, p. 12).

Tudo considerado e somado, Nietzsche só pode exclamar: "Não sabem quem é Wagner: um grandíssimo ator! Existe no teatro influência mais profunda, de maior peso?" (NIETZSCHE, 1999b, p. 25). O problema é que "não lhe opõe resistência", e "o fato de não lhe oporem resistência já é, em si, um sinal de décadence. O instinto está debilitado" (NIETZSCHE, 1999b, p. 18). Com isso Nietzsche conclui que "Wagner é um sedutor em grande estilo" (NIETZSCHE, 1999b, p. 36):

Nada existe de cansado, de caduco, de vitalmente perigoso e de caluniador do mundo, entre as coisas do espírito, que a sua arte não tenha secretamente tomado em proteção é o mais negro obscurantismo, o que ele esconde nos mantos de luz do ideal. Ele incensa todo instinto niilista (budista), e o transveste em música, ele incensa todo cristianismo, toda forma de expressão religiosa da décadence. Abram seus olhos: tudo o que jamais cresceu no solo da vida empobrecida, toda a falsificação que é a transcendência e o Além tem na arte de Wagner o seu mais sublime advogado não por fórmulas: Wagner é muito sagaz para se exprimir em fórmulas, mas por uma persuasão da sensualidade, que por sua vez torna o espírito cansado e gasto. A música como Circe [...] (NIETZSCHE, 1999b, p. 36-37).

A música de Wagner age como Circe do mesmo modo que o ideal ascético também o faz [cf. "Para a genealogia da moral”, III, § 2 e “Aurora”, § 332;

\footnotetext{
${ }^{28}$ As artes usadas como narcótico para o "homem fraco", contemporâneo: “[c]om que malícia escutamos agora o barulho de grande feira com que o homem 'culto' e citadino se deixa violentar por arte, livros e música até sentir 'prazeres espirituais', não sem ajuda de bebidas espirituais! Como agora nos fere os ouvidos o grito teatral da paixão, como se tornou estranho ao nosso gosto esse romântico tumulto e emaranhado de sentidos que o populacho culto adora, e todas as suas aspirações ao excelso, elevado, empolado!" (NIETZSCHE, 2001, p. 14; cf. id., §§ 86, 89 e 96).

29 "Direi ainda uma palavra para os ouvidos mais seletos: o que espero realmente da música. Que seja alegre e profunda como uma tarde de outubro. Que seja singular, travessa, terna, uma doce mulherzinha de baixeza e encanto... [...] Não sei distinguir música de lágrimas" (NIETZSCHE, 1995, p. 45-46).
} 
v. KOFMAN, 1994, p. 199-200]: transforma os homens em "porcos", quer dizer, não permite que eles saiam de um estado de indigência, de uma organização interna malograda, impedindo assim o desenvolvimento de instintos superiores, da “espiritualidade" na concepção nietzscheana.

Essa chamada "sedução" parece constituir para Nietzsche um importante elemento de sua crítica: assim como Wagner, também Jesus é sedutor [cf. "Para a genealogia da moral", I, $\left.\S 8^{30}\right]$; que significa isso? Jesus, enquanto "profeta", fundador de religião, é mais um "daqueles horrendos híbridos de doença e vontade de poder" (NIETZSCHE, 1995, p. 19); esse tipo é fanático, ele prega, exige fé de seus ouvintes [cf. id.]. Esses traços, entre outras coisas, os separam do Zaratustra de Nietzsche: este não é um sedutor, não pode sê-lo, pois sua postura para com aqueles que o ouçam é a oposta (NIETZSCHE, 1995, p. 19) Roger Hollinrake aponta "a semelhança entre as infernais 'donzelasflores' de Klingsor, no Parsifal, e o bando de homens superiores na Parte IV de Assim falou Zaratustra, surgidos por encanto, num momento crucial da história, com a finalidade de desviar o herói de seu propósito mais sério" (HOLLINRAKE, 1986, p. 169). Tal desvio diz respeito à tarefa do indivíduo, seja ele Odisseu, Zaratustra, ou Nietzsche; no caso deste filósofo, o pior desvio possível seria o da compaixão (HOLLINRAKE, 1986, p. 173-187), conforme se depreende de passagens de "Assim falou Zaratustra" 31 .

\section{Teatro; "Teatralidade"}

Cabe notar, como ressalva, que, como na maioria dos casos, também nessa crítica Nietzsche não é maniqueísta: ele chega a conceder ao teatro também uma influência positiva, na formação da "espiritualidade" [cf. "A gaia ciência", § 78 e, por extensão, § 107]; e há ainda, num aforismo de "Para além de bem e mal", uma valoração relativamente positiva, ao menos esperançosa, do homem moderno como ator, farsante, burlesco, preparado para "o Carnaval de grande estilo" (NIETZSCHE, 1992, p. 128). Esse texto é mais um caso em que a leitura se faz enriquecida (e talvez dificultada) pelo perspectivismo nietzscheano, que consegue apontar aspectos negativos e positivos a respeito de um mesmo ponto analisado ${ }^{32}$. No caso, parte-se do diagnóstico crítico do homem contemporâneo: “O mestiço europeu -um plebeu razoavelmente feio, afinal de contas- precisa absolutamente de um traje de fantasia: ele tem necessidade da história como um depósito de fantasias"(NIETZSCHE, 1992, p. 128); e, no entanto, essa necessidade de fundo decadente também pode ocasionar uma contribuição positiva para o tipo homem, pois promove um repertório para o referido "Carnaval de grande estilo", i.e., "para a mais espiritual gargalhada e exuberância momesca, para a altura transcendental da suprema folia e derrisão aristofânica do mundo." (NIETZSCHE, 1992, p. 128). Essa é uma contribuição que pode ser considerada "positiva" porque vai ao encontro do cultivo da não-seriedade, pertencente ao espírito livre e à gaia ciência: "Talvez descubramos precisamente aqui o domínio da nossa invenção, esse domínio em que também nós ainda podemos ser originais, como parodistas da história universal e bufões do Senhor, quem sabe. Talvez, se nada mais do presente existir no futuro, justamente a nossa risada tenha futuro!" (NIETZSCHE, 1992, p. 128 ).

Estendendo ainda esta relativização da crítica ao "teatro" [v. também "A gaia ciência”, § 78], cabe buscar uma especificidade que permita

\footnotetext{
30 "Esse Jesus de Nazaré, evangelho vivo do amor, esse 'redentor' portador da vitória e da bem-aventurança aos pobres, aos doentes e aos pecadores não era ele a sedução em sua forma mais inquietante e irresistível, a sedução e a via sinuosa para justamente aqueles valores judeus e inovações judaicas do ideal?” (NIETZSCHE, 1998, p. 27).

${ }^{31}$ V. "Assim falou Zaratustra", IV, O grito de socorro.

32 Isso acontece, a propósito, também no parágrafo de "Para além de bem e mal" que se segue, a respeito do moderno "retorno a Homero".
} 
separar alguns aspectos que se mostram um tanto sobrepostos. Primeiro: como na quase totalidade das ocasiões, o termo "teatro" apresenta-se polissemicamente em suas ocorrências. Há não muitos trechos em Nietzsche fala diretamente de teatro no uso corrente, stricto sensu, ou seja, como uma forma definida de manifestação artística; e quando o faz, é sempre rigoroso em suas críticas:

No teatro se é honesto apenas enquanto massa; enquanto indivíduo se mente, mente-se para si mesmo. O indivíduo deixa a si mesmo em casa quando vai ao teatro, renuncia ao direito de ter a própria escolha, a própria língua, ao direito a seu gosto, mesmo a sua coragem, como a temos e exercitamos entre as nossas quatro paredes, em oposição a Deus e o mundo. Ninguém leva consigo ao teatro os mais finos sentidos da sua arte, nem o artista que trabalha para o teatro (NIETZSCHE, 2001, p. 270-271); [o teatro é] sempre algo abaixo da arte, sempre algo secundário, tornado grosseiro, algo torcido, ajeitado, mentido para as massas! [...] O teatro é uma forma de demolatria em matéria de gosto, o teatro é uma rebelião das massas, um plebiscito contra o bom gosto [...] (NIETZSCHE, 1999b, p. 36).

Talvez se possa traçar uma via de explicação para tão duras apreciações a partir das considerações de Nietzsche acerca da natureza comunicativa isto é, utilitária e gregária da linguagem, da verbalização.
Para Nietzsche, o antecedente da emergência da linguagem é uma necessidade coletiva de comunicação animal; e como a cada necessidade corresponde uma força (ou uma fraqueza),

[...] o poder de comunicação determina-se em função da necessidade de comunicação. Não somente o ser humano, também os animais são tanto mais capazes de se comunicar quanto mais carentes de comunicação. O que existe, portanto, é uma relação entre a força, o grau de desenvolvimento da consciência e a necessidade de comunicação (GIACOIA, 2001, p. 33-34).

Ora, "Isso implica que nossas pretensões discursivas e comunitárias serão aquelas que nos remetem ao socius, ao próximo, e nos bloqueiam as vias de acesso ao próprio, ao si mesmo, tornando a consciência e a linguagem reféns do gregário, do identitário, do inautêntico" (GIACOIA, 2001, p. 40). Essa verificação é de seminal importância para o pensamento de Nietzsche como um todo ${ }^{33}$; e, quanto ao ponto aqui em vista, pode-se especular que a denúncia da "perspectiva de rebanho" (ou seja, "dos fetiches e hipóstases atávicas gestadas no seio do "gênio da espécie"” (GIACOIA, 2001, p. 43) esteja por trás da valorização da comunicabilidade humana seja uma provável razão para a indisposição de Nietzsche para com o teatro. Embora com certa restrição em boa dose arbitrária (que talvez seja a adotada por Nietzsche, ao menos em parte de suas críticas), cabe entender o teatrocomo uma forma

\footnotetext{
33 A principal conseqüência dessa genealogia da comunicabilidade é sem dúvida a destruição da idéia de alma unitária. Admitindo que "Poderíamos cumprir todas as nossas funções psíquicas superiores, tais como: querer, pensar, sentir, recordar, agir, sem necessidade do recurso à função da consciência" (GIACOIA, 2001, p. 32), então se percebe que "existe um vínculo essencial entre consciência e comunidade (sociedade) isto é, não fora a necessidade da vida em comum, não haveria consciência." (GIACOIA, 2001, p. 36); e disso se segue que a consciência "não somente não pode mais reivindicar para si o estatuto privilegiado de uma faculdade essencial, fazendo parte da própria natureza do ser humano, no sentido em que fora entendida pela filosofia tradicional. Também a consciência pode ter sua proveniência vinculada a um vir-a-ser, a um processo de constituição, a uma espécie de préhistória. Sendo assim, ela não pode mais ser simplesmente identificada com a essência ou com o núcleo perene da subjetividade." (GIACOIA, 2001, p. 36). Eis porque "uma das razões fundamentais pelas quais Nietzsche se considera o primeiro psicólogo da Europa é porque o seu empreendimento crítico consiste, no essencial, em desconstituir, ou, dito de maneira mais radical e fiel ao projeto, em destruir essas pilastras metafísicas sobre as quais se assentava não somente a psicologia racional, como também as bases teóricas da psicologia em geral, pelo menos até o momento em que Nietzsche escreve sua obra." (GIACOIA, 2001, p. 22). "Dessa maneira, se o próprio Freud reconhece que o pressuposto fundamental da psicanálise consiste na diferenciação entre instâncias do psiquismo, então já podemos compreender melhor a razão pela qual Nietzsche pode se arvorar em primeiro da Europa: psicólogo na exata medida em que, para ele, o reconhecimento de processos psíquicos inconscientes, ou a dissociação entre a subjetividade e a unidade da consciência dito metafisicamente, a dissolução da unidade substancial da 'alma' constitui um dos principais efeitos de sua crítica da moral, da religião e da metafísica" (GIACOIA, 2001, p. 25-26).
} 
de arte que, por essência, privilegia a comunicação verbal como meio e matéria, que busca, com a fala (aliada ou não ao gesto), envolver e dominar a consciência de todos os espectadores de igual maneira e em mesma intensidade. Talvez com essa via de explicação possa-se apreender mais a fundo o significado de porque Nietzsche considera que no teatro "somos povo, público, horda, mulher, fariseu, gado eleitor, democrata, próximo, semelhante, mesmo a consciência mais pessoal sucumbe à magia niveladora do 'grande número', a estupidez influi como lascívia e contágio, o 'próximo' governa, tornamo-nos próximo[...]” (NIETZSCHE, 2001, p. 271).

Seja como for, há de se perceber que, na maior parte das vezes, Nietzsche não parece se referir ao teatro stricto sensu, mas sim a uma certa "teatralidade", entendida como imanente e generalizada falsidade, que se lhe afigura como característica típica da modernidade. Assim, uma crítica da modernidade incluiria forçosamente uma crítica das artes modernas; e seria acompanhada, em seu aspecto positivo, de "indicações para um tipo contrário que é o menos moderno possível, um tipo nobre, que diz Sim" (NIETZSCHE, 1995, p. 95). Essas verificações novamente reforçam a leitura, aqui apresentada, acerca da figura de Wagner "ator" como sendo tomada por Nietzsche enquanto sintoma e agravante da décadence moderna. No contexto da Terceira Dissertação, essa concepção de falsidade está imiscuída na análise da arte corrompida pelo ideal ascético (Wagner) e, mais ao final, na consideração do inimigo interior deste ideal, o seu "comediante" [v. "Para a genealogia da moral”, III, $\S \S 26$ e 27].

\section{Ator e Décadent: Sintoma da Modernidade}

Sendo "grandíssimo ator" e um decadente “perfeito", Wagner é para Nietzsche o exemplo mais acabado do que constitui a modernidade: formados pela mistura de instintos opostos que se desenrolou ao longo da história (e da préhistória), nos vemos aquém de uma organização nobre, hierarquicamente sintonizada, e, com isso, tendemos para o "teatro". Ambas as características (ser décadent e ser ator) se evidenciam em sua arte; esta é sintoma e agravamento, mas não causa da "ruína da música" [cf. "O caso Wagner”, Segundo Pós-Escrito]. Wagner "é o artista moderno par excellence" (NIETZSCHE, 1999b, p. 19); e, supondo que se quisesse proceder a " $U m$ diagnóstico da alma moderna, por onde começaria ele? Por uma resoluta incisão nesta contradição instintiva, pelo desvendamento de seus valores opostos, pela vivissecção do caso mais instrutivo" (NIETZSCHE, 1999b, p. 45). Esse é o caso de uma artista que se despede da vida dando à luz uma obra que é nada menos que um "rebento de um ensandecido ódio ao conhecimento, ao espírito e à sensualidade", uma "maldição aos sentidos e ao espírito e ao espírito em um hausto de ódio", uma "apostasia e um retorno a ideais cristão-mórbidos e obscurantistas"; "[e] por fim até mesmo negação e cancelamento de si mesmo, por parte de um artista que com todo o poder da sua vontade até então perseguira o oposto, ou seja, a mais alta espiritualização e sensualização de sua arte [...] E não só da sua arte: também da sua vida" (NIETZSCHE, 1998, p. 90). O que Nietzsche quer alcançar expondo tal caso "mais instrutivo" sobre a modernidade, o "caso" Wagner, é que se combata a decadência da arte e a teatrocracia generalizada ${ }^{34}$.

A essa altura já deve estar claro que Nietzsche não parte de um "conceito" de Modernidade para com ele criticar seus alvos e ele nem o poderia fazer, sob pena de ir contra as diretrizes metodológicas mais básicas de sua genealogia. O que ele faz é construir uma leitura, uma situação à qual, pelos traços dominantes, lhe parece justo caracterizar como

\footnotetext{
34 "Mas quem ainda tem dúvidas quanto ao que quero quanto às três exigências a que desta vez minha ira, minha preocupação, meu amor à arte deram voz? Que o teatro não se torne senhor das artes.Que o ator não se torne sedutor dos autênticos. Que a música não se torne uma arte da mentira" (NIETZSCHE, 1999b, p. 33).
} 
sendo a típica da "Modernidade"; e só pode fazêlo, "nietzscheanamente", através do recurso a tipos referenciais, exemplos sintomáticos, argumentos ad hominem (SOLOMON, 1996). Por isso, faz-se tão fundamental para Nietzsche o tal "caso" de Wagner, a ponto de dedicar-lhe dois livros inteiros em um mesmo e decisivo ano (1888), o que se confirma de maneira definitiva pelo seguinte trecho:

nunca ataco pessoas sirvo-me da pessoa como uma forte lente de aumento com que se pode tornar visível um estado de miséria geral porém dissimulado, pouco palpável. [...] Assim ataquei Wagner, ou mais precisamente a falsidade, a bastardia de instinto de nossa "cultura", que confunde os sofisticados com os ricos, os tardios com os grandes (NIETZSCHE, 1995, p. 32).

\section{Conclusão}

Como já visto, a conversão a Schopenhauer marca também a "veleidade de artista" no caso de Wagner: "Wagner precisava de literatura para convencer todo o mundo a levar seriamente, levar profundamente a sua música, 'porque significava coisas infinitas'; durante a vida ele foi o comentador da 'idéia"' (NIETZSCHE, 1999b, p. 30) ou seja: veleidade no lugar da boa-consciência de artista. E se a "primeira sentença" da estética nietzscheana seja "O que é bom é leve, tudo divino se move com pés delicados" (NIETZSCHE, 1999b, p. 11), não é de estranhar que Nietzsche conclua que o que falta em Wagner é, precisamente, "la gaya scienza", ou seja: "os pés ligeiros; engenho [Witz]; fogo; graça” (NIETZSCHE, 1999b, p. 31). Como a arte é (deveria ser) o modelo para a gaia ciência, então Wagner constitui "talvez o maior exemplo de autoviolentação na história das artes" (NIETZSCHE, 1999b, p. 33).

A partir de todas as observações precedentes é que se poderia querer considerar, com alguma propriedade, a função do recurso a Wagner nos $\S \S$ 2-5 da Terceira Dissertação de "Para a genealogia da moral". Em resumo, o que se depreende é: o artista deveria ser (tem condições de ser) o oposto do asceta; mas, como toda a humanidade moderna encontra-se comprometida pela décadence (e por isso, também comprometida com ela), mesmo a mais poderosa das artes, a música, está corrompida haja visto o maior exemplo tanto de decadência quanto de inautenticidade artística e musical, Richard Wagner.

\section{Referências}

ABEL, Günter. Verdade e interpretação. Veritas, Porto Alegre, v. 47, n. 1, p. 41-51, 2002.

AULETE, Caldas. Dicionário contemporâneo da língua portuguesa. 3. ed. Rio de Janeiro: Delta, 1974. p. 1608.

DELEUZE, Gilles. Nietzsche. Paris: PUF, 1965.

GIACOIA JUNIOR, Oswaldo. Nietzsche como psicólogo. São Leopoldo: UNISINOS, 2001.

HELLER, Erich. The importance of Nietzsche: ten essays. Chicago: University of Chicago, 1988.

HOLLINRAKE, Roger. Nietzsche, Wagner e a filosofia do pessimismo. Rio de Janeiro: Zahar, 1986.

KOFMAN, Sarah. Wagner's ascetic ideal according to Nietzsche. In: SCHACHT, Richard (Ed.). Nietzsche, genealogy, morality: essays on Nietzsche's genealogy of morals. Los Angeles: University of California, 1994. p. 193-213.

MAY, Simon. Nietzsche's ethics and his war on “morality”. Oxford: Oxford University, 1999.

MÜLLER-LAUTER, Wolfgang. Décadence artística enquanto décadence fisiológica. A propósito da crítica tardia de Friedrich Nietzsche a Richard Wagner. Cadernos Nietzsche, São Paulo, n. 6, p. 11-30, 1999.

NIETZSCHE, Friedrich W. Além do bem e do mal: prelúdio a uma filosofia do futuro. São Paulo: Companhia das Letras, 1992.

. O anticristo. Tradução de Pietro Nassetti. São Paulo: Martin Claret, 2003.

. Ecce homo: como alguém se torna o que é. São Paulo: Companhia das Letras, 1995.

. Genealogia da moral: uma polêmica. São Paulo: Companhia das Letras, 1998.

. Obras incompletas. In: LEBRUN, Gerard (Ed.). Nietzsche. São Paulo: Nova Cultural, 1999a. (Coleção Novos Pensadores) 
. O caso Wagner: um problema para músicos: Nietzsche contra Wagner: dossiê de um psicólogo. São Paulo: Companhia das Letras, 1999b.

A gaia ciência. São Paulo: Companhia das Letras, 2001.

. Crepúsculo dos ídolos: como se filosofa com o martelo. São Paulo: Companhia das Letras, 2006.

SCHACHT, Richard. Nietzsche. In: HONDERICH, Ted (Ed.). Nietzsche. London: Routledge \& K. Paul, 1983. (Col. The arguments of the philosophers).

. Nietzschean cognitivism. Nietzsche-Studien, v. 29, p. 12-40, 2000.

SOLOMON, Robert. Nietzsche ad hominem: perspectivism, personality, and ressentiment revisited. In: HIGGINS, Kathleen; MAGNUS, Bernd (Ed.). The Cambridge companion to Nietzsche. Cambridge: Cambridge U., 1996. p. 180-222. 